DOI 10.14746/ssp.2017.3.7

Anna AnTCZAK

Uczelnia Łazarskiego

\title{
Rola aktorów niepaństwowych w ksztaltowaniu bezpieczeństwa
}

Streszczenie: Artykuł przedstawia analizę roli, jaką pełnią różni aktorzy niepaństwowi w kształtowaniu bezpieczeństwa globalnego. Zwraca uwagę na funkcje, jakie obecnie pełnią w tym procesie państwa oraz wskazuje, że ich rola stopniowo maleje na rzecz aktorów pozapaństwowych. Artykuł jednocześnie dostarcza klasyfikację tychże aktorów (organizacje rządowe, pozarządowe, korporacje, grupy zbrojne, think-tanki, diaspory, partie polityczne czy Kościół katolicki), różnicując ich znaczenie dla bezpieczeństwa międzynarodowego.

Słowa kluczowe: państwa, aktorzy niepaństwowi, bezpieczeństwo, korporacje, organizacje międzynarodowe

\footnotetext{
Zzęsto można się spotkać z tezą, iż aktorzy państwowi nadal odgrywają główną rolę w stosunkach międzynarodowych. Czy rzeczywiście tak jest? Przez wiele wieków państwa dominowały na arenie międzynarodowej, głównie dlatego, iż były w stanie zapewnić stabilność oraz dostarczyć określone dobra dla zbiorowości ludzkiej lepiej niż inni uczestnicy (Mann, 1993, s. 137). Miało to szczególne znaczenie zwłaszcza dla obszaru bezpieczeństwa, gdyż państwa dysponowały niemalże wyłącznym monopolem na posiadanie siły (sił zbrojnych). Jednak ostatnio zmiany zaczęły dotykać także i tego obszaru. Role państw, społeczeństw obywatelskich i aktorów niepaństwowych zmieniają się i są definiowane na nowo pod wpływem procesu, jakim jest modernizacja polityczna ${ }^{1}$. Celem niniejszego artykułu jest zatem zdefiniowanie roli aktorów niepaństwowych, jaką odgrywają obecnie w stosunkach międzynarodowych i jakie jest ich znaczenie dla kształtowania się bezpieczeństwa globalnego, także uwzględniając rozmaite typy tych podmiotów.

Znaczenie aktorów państwowych zmniejsza się, zaś rola pozostałych - zwiększa. Pojawianie się coraz większej liczby nowych aktorów poza-

1 Sformułowania tego użył B. Arts w: B. Arts, M. Noortmann, B. Reinalda (red.), Non-State Actors in International Relations, Ashgate, Aldershot 2001, s. 145.
} 
państwowych, a wraz z tym procesem - postępująca prywatyzacja stosunków międzynarodowych w znacznej mierze jest rezultatem rozpadu ZSRR i tym samym zniknięciem jednej z dwóch ówczesnych potęg światowych, a także powolne zmniejszanie się wpływów Stanów Zjednoczonych na świecie. Innym źródłem tego zjawiska jest zapotrzebowanie ze strony współczesnych gospodarek, dla których rynki krajowe były zbyt małe, by spełnić oczekiwania wszystkich uczestników i które w związku z tym potrzebowały możliwości ekspansji (międzynarodowej). Istotny był także czynnik technologiczny i jak twierdzą Jesselin oraz Wallace (2001), równoległy rozwój transnarodowych sieci społecznych, grup interesu (nacisku) oraz ruchów społecznych odzwierciedlał stopień zaawansowania w sferze technologicznej - zarówno pod kątem szerzenia świadomości na temat nowych zagrożeń, jak i szans, jakie dają nowoczesne technologie komunikacyjne oraz szybkość przemieszczania się. Ponadto obecnie bezpieczeństwo jest coraz bardziej związane z czynnikami pozamilitarnymi i właśnie dlatego aktorzy niepaństwowi (organizacje pozarządowe, społeczeństwa obywatelskie, korporacje czy media) uzyskują coraz większe znaczenie i wpływ na tę sferę, pozbawiając tym samym państwa części ich przywilejów.

Proces modernizacji politycznej doprowadził do odnowienia porozumień pomiędzy graczami publicznymi i prywatnymi lub pomiędzy aktorami państwowymi i niepaństwowymi w kwestiach obszarów odpowiedzialności (Arts, Noortmann, Reinalda, 2001, s. 42). Warto zatem zdefiniować pojęcie aktorów niepaństwowych, co nie jest zadaniem łatwym, gdyż zawiera ono w sobie całą gamę różnych podmiotów. B. Arts (2003, s. 5) uważa, że aktorzy niepaństwowi to tacy, którzy „nie są państwami bądź ich przedstawicielami, jednak działają na szczeblu międzynarodowych i są potencjalnie istotni dla stosunków międzynarodowych". Definicja ta koncentruje się na jednej z prerogatyw uczestnika stosunków międzynarodowych, a mianowicie zdolności do wywierania wpływu na innych międzynarodowych graczy. Josselin i Wallace (2001, s. 2-4), stwierdzając, że „definiowanie podmiotów niepaństwowych głównie przez pryzmat ich niezależności od państw i władzy państwowej byłoby mylące”, kierują się nieco innymi kryteriami i postrzegają jako podmioty niepaństwowe następujące organizacje:

- w dużej mierze lub całkowicie niezależne od finansowania i kontroli rządów centralnych: wywodzące się ze społeczeństwa obywatelskiego albo z gospodarki rynkowej lub z impulsów politycznych wykraczających poza kontrolę państwa; 
- działające lub uczestniczące w sieciach, które rozciagają się ponad granicami dwóch lub więcej państw i angażują się w relacje ponadnarodowe, łącząc systemy polityczne, gospodarkę i społeczeństwo;

- mające wpływ na politykę poprzez swoje działanie w jednym lub kilku państwach bądź w instytucjach międzynarodowych - przynajmniej częściowo w sposób celowy, uważając go za główny lub poboczny aspekt działalności.

Obecnie wiele przestrzeni międzynarodowej zajmuja najbardziej oczywiści (oprócz państw) aktorzy, a mianowicie organizacje międzynarodowe - rządowe i pozarządowe. Istnieje wiele przyczyn popularności tej formy podmiotów międzynarodowych. Przede wszystkim dają one większe możliwości interakcji i współpracy, a ich rozwój wynika ze ściślejszych i bardziej intensywnych stosunków międzynarodowych (kontaktów), rosnącej sieci współzależności globalnych, ekspansji wyzwań ponadnarodowych, niewydolności systemu państwowo-centrycznego w dostarczaniu rozwiązań dla bieżących problemów (zwłaszcza w zakresie bezpieczeństwa, gospodarki i kwestii społecznych), ale także możliwości umocnienia się mniejszych i słabszych państw oraz względnych sukcesów organizacji międzynarodowych jako alternatywy dla współpracy dwustronnej lub niezależnego aktora (Rourke, 2008). Pewną odmianą organizacji międzyrządowej jest organizacja ponadnarodowa ${ }^{2}$, która łączy elementy międzyrządowe $\mathrm{z}$ „,bardziej ugruntowaną formą rządu o charakterze międzynarodowym [...] z władzą która działa ponad suwerennością swoich członków" (Rourke, 2008, s. 202-203). Organizacje pozarządowe zaś mają możliwość nacisku na rządy, co jest szczególnie skuteczne w środowisku międzynarodowym. Jak zauważa Reinalda (1997), wpływają one również na zachowanie państw dzięki realizowaniu statusu doradczego, lobbingowi lub poprzez zwracanie się do opinii publicznej, a także wdrażanie procesów monitorowania ich działalności, w których organizacje te uczestniczą.

Hameiri i Jones (2013, s. 465) twierdzą, że obecnie można zaobserwować „dezagregację państw narodowych oraz wzrost regulacyjnego i wielopoziomowego sprawowania rządów". Poziom krajowy nie jest już najbardziej oczywisty dla globalnego sprawowania rządów. Mimo że państwa mają pewne ograniczenia w odniesieniu do meta-zarządzania (meta-governance), to nadal starają się nadzorować wszystkie moż-

\footnotetext{
${ }^{2}$ Najlepszym przykładem jest Unia Europejska.
} 
liwe prywatne i publiczne podmioty regulacyjne (Abrahamsen, Williams, 2011; Jessop, 2009 oraz Sassen, 2006). Niechęć do przeniesienia systemu zarządzania poza poziom państwa narodowego może wynikać z obawy przed utratą demokratycznej kontroli nad podmiotami pozostającymi poza instytucjami kontrolowanymi przez państwo (Hameiri, Jones, 2013).

Wielu naukowców zgadza się, że podmioty niepaństwowe odgrywają ważną rolę, nie tylko pod względem bezpośredniego wpływu, jaki wywierają na stosunki międzynarodowe, ale także pod względem instytucjonalizacji ich wymiarów prawnych i politycznych. Nie ulega wątpliwości, że odgrywają one istotną rolę w tworzeniu i utrzymywaniu międzynarodowych reżimów i sprawowaniu rządów na poziomie globalnym, jak również w zmianach normatywnych (Josselin, Wallace, 2001) oraz prawie wszystkich procesach globalizacji. Ich znaczenie i percepcja różnią się w odniesieniu do przyjętej perspektywy teoretycznej i paradygmatu. W odniesieniu do państwo- i rządowo-centrycznego realizmu, znaczenie podmiotów niepaństwowych będzie żadne lub co najwyżej minimalne. W nurcie funkcjonalizmu, ich znaczenie zostanie zredukowane do określonych funkcji, głównie technicznych. Pluraliści zaś postrzegają aktorów niepaństwowych jako reprezentantów określonych interesów pomagających $\mathrm{w}$ adaptacji. Transnarodowcy łączą podmioty niepaństwowe $\mathrm{z}$ międzynarodowym standardem i inżynierią społeczną, a zwolennicy zbiorowej teorii działania społecznego postrzegaja je jako źródło lub czynnik powodujący zmiany społeczno-polityczne (Arts, Noortmann, Reinalda, 2001). Różnice te podsumowano bardziej szczegółowo w tabeli 1. Różni aktorzy maja odmienne zadania do wykonania. I tak grupy nacisku poszukują zmian w postaci adaptacji, które uwzględniałyby promowane interesy. Aktorzy prywatni zajmują się wprowadzaniem do porządku dziennego, a następnie wdrażają kwestie, które są pomijane lub niedostrzegane. I wreszcie, ruchy społeczne starają się przezwyciężyć ograniczenia i trudności w procesie transformacji.

Jednym z największych wyzwań związanych z podmiotami niepaństwowymi jest ich kategoryzacja. Prawdopodobnie najlepszy sposób poradzenia sobie z tym problemem został zaproponowany przez trio Arts, Noortmann i Reinalda, którzy podzielili je na cztery kategorie: organizacje pozarządowe zorientowane na interes publiczny (NGO), organizacje publiczne międzyrządowe (IGO), korporacje nastawione na zysk i grupy zbrojne (tabela 2). 
Stosunek do aktorów niepaństwowych

Tabela 1 w ramach różnych podejść teoretycznych

\begin{tabular}{||l|l|l|l|l|}
\hline \multicolumn{1}{|c|}{ Teoria } & \multicolumn{1}{|c|}{ Aktorzy } & \multicolumn{1}{|c|}{ Cel } & \multicolumn{1}{c|}{ Metoda } & \multicolumn{1}{c|}{$\begin{array}{c}\text { Rodzaj } \\
\text { wplywu }\end{array}$} \\
\hline Pluralizm & $\begin{array}{l}\text { Grupy nacisku } \\
\text { (oraz prywatne } \\
\text { organizacje) }\end{array}$ & $\begin{array}{l}\text { Reprezentacja inte- } \\
\text { resów }\end{array}$ & $\begin{array}{l}\text { Lobbying } \\
\text { i konsultacje }\end{array}$ & Adaptacja \\
\hline $\begin{array}{l}\text { Transnarodo- } \\
\text { wość }\end{array}$ & $\begin{array}{l}\text { Aktorzy pry- } \\
\text { watni }\end{array}$ & $\begin{array}{l}\text { Wywieranie wpływu } \\
\text { politycznego (także } \\
\text { instytucjonalnego } \\
\text { czy regulacyjnego) }\end{array}$ & $\begin{array}{l}\text { Uczestnictwo } \\
\text { i doradztwo } \\
\text { (ekspertyzy) }\end{array}$ & $\begin{array}{l}\text { Inżynieria spo- } \\
\text { feczna (socjo- } \\
\text { technika) }\end{array}$ \\
\hline $\begin{array}{l}\text { Zbiorowe dzia- } \\
\text { łanie społeczne }\end{array}$ & $\begin{array}{l}\text { Ruchy spo- } \\
\text { leczne } \\
\text { Zmiana polityczna } \\
\text { i społeczna }\end{array}$ & $\begin{array}{l}\text { Mobilizacja } \\
\text { i perswazja }\end{array}$ & Transformacja \\
\hline
\end{tabular}

Źródło: Opracowanie własne na podstawie B. Reinalda, Private in Form, Public in Purpose: NGOs in International Relations Theory, w: Non-State Actors in International Relations, red. B. Arts, M. Noortmann, B. Reinalda, Ashgate, Aldershot 2001, s. 17.

Tabela 2

Kategoryzacja aktorów niepaństwowych

\begin{tabular}{|c|c|c|c|}
\hline $\begin{array}{l}\text { Organizacje } \\
\text { pozarządowe }\end{array}$ & $\begin{array}{c}\text { Organizacje } \\
\text { międzyrządowe }\end{array}$ & Korporacje & Grupy zbrojne \\
\hline \begin{tabular}{||l} 
- \\
- dotowane przez dar- \\
czyńców \\
- dotowane przez rzą- \\
dy \\
- zależne od państwa \\
- inicjatywy oddolne \\
- organizacje pożytku \\
publicznego \\
- międzynarodowe or- \\
ganizacje pozarządo- \\
we \\
- ruchy społeczne
\end{tabular} & 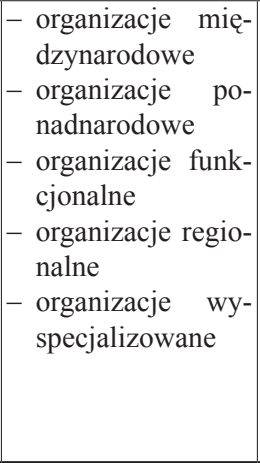 & $\begin{array}{l}\text { - } \text { korporacje wielo- } \\
\text { narodowe } \\
\text { - korporacje trans- } \\
\text { narodowe } \\
\text { - korporacje naro- } \\
\text { dowe aktywne } \\
\text { międzynarodowo }\end{array}$ & $\begin{array}{l}\text { - Ruchy powstań- } \\
\text { cze } \\
\text { - Ruchy wyzwoleń- } \\
\text { cze } \\
\text { - Zorganizowane } \\
\text { grupy przestępcze } \\
\text { - Terroryści }\end{array}$ \\
\hline
\end{tabular}

Źródło: B. Arts, M. Noortmann, B. Reinalda, Non-State Actors in International Relations, Ashgate, Aldershot 2001, s. 304.

Powyższa klasyfikacja nie obejmuje jednak takich podmiotów jak grupy biznesowe, think-tanków czy mediów, które niekoniecznie są korporacjami i nie mogą być także sklasyfikowane jako ruchy społeczne. Mogły być sklasyfikowane jako inne grupy wpływów, szczególnie że think-tanki i media wywierają znaczący wpływ na kształtowanie się opinii publicz- 
nej. Powstaje także pytanie o wpływowe jednostki takie jak biznesmeni czy celebryci, którzy osobiście, a nie za pomocą jakiegokolwiek zinstytucjonalizowanego narzędzia, mają wpływ na stosunki międzynarodowe - czy także powinni być postrzegani w kategoriach aktorów niepaństwowych. Problem ten nie jest łatwy do rozstrzygnięcia i wymaga dalszych szczegółowych badań, ponieważ jest on zarówno interesujący, ale także istotny z punktu widzenia określenia znaczenia jednostek dla stosunków międzynarodowych i możliwości ich sklasyfikowania dla celów poznawczych.

Istnieją pewne czynniki, które pomagają podmiotom niepaństwowym działać na arenie międzynarodowej i wypełnić lukę między instytucjami rządowymi a społeczeństwem. Są one trafnie zidentyfikowane i opisane przez Alstona (2005) i obejmują:

- prywatyzację;

- mobilizację kapitału;

- liberalizację handlu i jej konsekwencje w zakresie zatrudnienia;

- poszerzanie horyzontów instytucji wielostronnych;

- rozpowszechnianie idei społeczeństwa obywatelskiego;

- prywatyzację sfery bezpieczeństwa;

- zmianę charakteru konfliktów.

Arts, Noortmann i Reinalda (2001, s. 301) stworzyli także ciekawą klasyfikację „istotności” podmiotów niepaństwowych. Rozróżniają między instytucjonalnym i strategicznym znaczeniem podmiotów niepaństwowych na arenie międzynarodowej. Znaczenie instytucjonalne dotyczy osobowości prawnej, autonomii, podsystemów i ustaleń politycznych, jak również ponadnarodowych koalicji określonych grup interesu. Oddziaływanie strategiczne związane jest z możliwością wywarcia wpływu na dyskurs polityczny, proces podejmowania decyzji, ustalaniem porządku określonych obrad, tworzeniem prawa i ustalaniem standardów międzynarodowych, rozpowszechnianiem wartości i norm, wkładem we wdrożenie prawa międzynarodowego lub ponadnarodowego, a także norm i standardów we własnym kraju oraz budowaniem społeczeństwa obywatelskiego. Ta kategoryzacja pokazuje, że podmioty niepaństwowe mają ogromny potencjał w dziedzinie procesów tworzenia instytucji, ale także w kwestiach społeczno-politycznych. Szeroka gama rodzajów wpływów podmiotów niepaństwowych wskazuje, że staną się one coraz ważniejszymi podmiotami w już istniejących dziedzinach, ale najprawdopodobniej również w innych. Jak podkreśla Arts (2003, s. 56), „podmioty niepaństwowe stały się ważniejszymi graczami z powodu roz- 
szerzenia koalicji politycznych, rozpowszechniania władzy, pluralizacji zasad i rozszerzenia dyskursu" oraz częściowego zastąpienia (lub raczej rozszerzenia) polityki międzyrządowej ponadnarodową poprzez włączenie podmiotów niepaństwowych jako graczy zinstytucjonalizowanych.

Międzynarodowi aktorzy niepaństwowi są na ogół bardziej wydajni i mają więcej swobody działania, ponieważ nie muszą poświęcić zbyt wiele uwagi władzom krajowym związanym z rządem i instytucjami państwa narodowego. Poza wyżej wymienionymi doświadczeniami w różnych dziedzinach, jak również znajomością i zaufaniem konkretnych grup społecznych czy zawodowych, podmioty niepaństwowe często posiadają rozległe zasoby (w odniesieniu do kwestii finansowych, krajowych i międzynarodowych kontaktów, zasobów ludzkich i profesjonalizmu), są bardzo mile widziane przez media w roli niezależnych ekspertów, a tym samym cieszą się szacunkiem konkretnych kręgów i wreszcie mają potencjał budowania sojuszy - tak między sobą, jak i z innymi podmiotami, co daje im silną pozycję podczas negocjacji i możliwości mobilizacji silnych grup nacisku i instytucji. Przyczyniają się również do określania kodeksów moralnych i wzorów zachowań w stosunkach międzynarodowych.

Jak zauważa Reinalda (1997), aktorzy niepaństwowi są stymulującymi partnerami zarówno dla rządów, jak i organizacji międzynarodowych ze względu na posiadane umiejętności i kompetencje. Rządy państw starają się kontrolować organizacje pozarządowe i inne podmioty niepaństwowe, aby lepiej służyły ich interesom politycznym (w odniesieniu do wymiaru narodowego, tzn. poparcia wyborów) i budowaniu pozycji międzynarodowej. Próbują także kontrolować związki między organizacjami krajowymi i międzynarodowymi a podmiotami niepaństwowymi, aby zapobiec budowaniu potencjalnych koalicji przeciwko interesom rządów. Z kolei organizacje międzynarodowe, które nie podlegają tej kontroli, są bardziej chętne do współpracy z organizacjami pozarządowymi i innymi podmiotami niepaństwowymi. Aktorzy niepaństwowi, a zwłaszcza organizacje pozarządowe mogą służyć jako platformy dyskusyjne i źródła większej świadomości społecznej.

Podmioty niepaństwowe odnoszą sukcesy w obszarach wolontariackich i pomocowych, wspierają kobiety i dzieci, a także uchodźców. Są to obszary, w których państwa często zawodzą lub zakres ich działania nie jest wystarczający. Pojawienie się aktorów niepaństwowych i ich rosnące znaczenie jest wynikiem rozczarowania z powodu niedostatecznej efektywności państw w niektórych obszarach, zwłaszcza tych ukie- 
runkowanych społecznie. Czasami aktorzy szczebla lokalnego są lepiej przygotowani do organizowania i kierowania określonymi projektami (Stiles, 2005). Mają szersze doświadczenia i są lepiej „zakorzenione” w środowisku/otoczeniu (w odniesieniu do funkcjonalności, specjalizacji lub wiedzy na temat lokalnych potrzeb i ich specyfiki). Informacje, które posiadają i wiedza, którą mogą dostarczyć, są przydatne zarówno dla społeczeństwa, jak i dla państw narodowych (rządów).

Niemniej jednak większość badaczy twierdzi, że w odniesieniu do międzynarodowych ram prawnych to nadal państwa odgrywają główną rolę w stosunkach międzynarodowych. Formalne uczestnictwo innych graczy jest ograniczone, nawet jeśli ich potencjał może być ogromny, dlatego często są to pożądani partnerzy na etapie dyskusji w procesie podejmowania decyzji (Alston, 2005). Twierdzi się również, że podmioty te powinny przejąć część odpowiedzialności w tej dziedzinie oraz zaakceptować pewne obowiązki moralne (dotyczy to głównie korporacji). Niemniej jednak pojawia się kwestia odpowiedzialności za działania podmiotów niepaństwowych w zakresie sprawowania funkcji publicznych. Jeśli państwa nie realizują konkretnych działań, czy nadal są za nie odpowiedzialne? Reinish (2005) oferuje dwa rozwiązania, czyli pośrednią odpowiedzialność państw za działania aktorów niepaństwowych lub bezpośrednią odpowiedzialność podmiotów niepaństwowych na mocy prawa międzynarodowego i przed sądami międzynarodowymi. Wpływ aktorów niepaństwowych nie zawsze jest pozytywny, gdyż oni niekoniecznie działają z pobudek altruistycznych, a ich naciski i lobbing są dostosowywane do własnych interesów (nie muszą przemawiać w imieniu społeczeństwa obywatelskiego). Zdarza się również, że „organizacje pozarządowe, nawet te, które popierają demokrację i praworządność, same nie są demokratyczne" (Kamminga, 2005, s. 111).

Przedsiębiorstwa wielonarodowe są jednym z najbardziej znaczących podmiotów niepaństwowych ze względu na ich wielkość, liczbę i funkcjonowanie na głównych rynkach i sektorach przemysłu (Muchliński, 2010). Zwykle pozostają niezaangażowane w sprawy polityczne (czasami jednak chcą zwiększać zasoby, które mają być wykorzystane w kampaniach politycznych), a głównym celem ich działania jest zwiększenie zysków (w związku z tym nie będą angażować się w politykę, jeśli ta nie będzie służyć ich interesom) oraz maksymalizacja własnej użyteczności (w przeciwieństwie do organizacji non-profit, które mają na celu promowanie spraw publicznych na arenie międzynarodowej (Breitmeier, 2008)). Z punktu widzenia struktury własności istnieją dwa podstawowe 
typy korporacji: korporacje ponadnarodowe (których aktywa należą do spółki dominującej, ale działają w co najmniej dwóch krajach, posiadają siedzibę w kraju macierzystym i kilka oddziałów w innych krajach) oraz korporacje wielonarodowe (których aktywa są tylko częściowo własnością firmy macierzystej, zaś pozostała część jest zorganizowana albo na zasadzie joint venture, albo należy do innych międzynarodowych przedsiębiorstw, a więc kapitał korporacyjny jest międzynarodowy). Oba typy korporacji rozwijają się poprzez zagraniczne inwestycje bezpośrednie. Międzynarodowe korporacje mają specyficzne cechy, takie jak przede wszystkim suwerenność oparta na ogromnym potencjale gospodarczym i finansowym, który pozwala im podejmować decyzje niezależnie od interesów państw, w których działają. Są również geograficznie rozproszone oraz strukturalnie i organizacyjnie złożone. W większości przypadków są one wysoce wyspecjalizowane i wykorzystują koncepcję globalnej skuteczności, opierając się na optymalizacji podziału zadań i obniżaniu kosztów. Niemniej jednak posiadają również zdolność arbitrażu, adaptacji, integracji i elastyczności przy wykorzystaniu preferencyjnych różnic w systemach prawnych i podatkowych, zasobach, cenach, efektywności produkcji itp. krajów, w których działają.

Działalność korporacji międzynarodowych odgrywa ważną rolę w gospodarce światowej, ponieważ służą one rozwojowi i stymulują zmiany. Czynią to poprzez realizację polityki ekspansji (w zakresie inwestycji, współpracy i handlu), przepływu zasobów i zdolności produkcyjnych, stymulowania wzrostu gospodarczego i zwiększania efektywności, przyczyniania się do restrukturyzacji przedsiębiorstw, aktywizację konkurencji i lokalnej przedsiębiorczości, przekazywanie metod i wzorców oraz wzmocnienie współpracy międzynarodowej (Białoskórski, 2010). Działalność korporacji międzynarodowych może być również szkodliwa zwłaszcza dla gospodarek krajów przyjmujących, a tym samym powodować zagrożenia dla bezpieczeństwa poprzez wywoływanie niezadowolenia społecznego i niepokojów, a także ekonomiczny drenaż tegoż kraju. Zachowanie korporacji międzynarodowych może prowadzić do praktyk ograniczających konkurencję, marginalizacji krajowych przedsiębiorstw, drenażu lokalnych rynków oraz zaawansowanych zasobów produkcji (zarówno w odniesieniu do zasobów naturalnych, jak i siły roboczej, ale także technologii i know-how) lub oligopolu.

Problemy, na których koncentrują się koncerny międzynarodowe są raczej natury szczegółowej niż ogólnej (demokracja, opinia publiczna, prawa człowieka itp.). Z jednej strony ten typ podmiotów jest istotny dla 
określania międzynarodowych standardów biznesowych i etycznych, a także rozpowszechniania praworządności w biznesie. Społeczność przedsiębiorców (biznesowa) odgrywała ważną rolę w ustanawianiu reguł, norm i preferencji zachowań w państwach, lecz nie została prawidłowo rozpoznana i doceniona (Haufler, 1997). Biorąc pod uwagę doświadczenie, fachową wiedzę i zasoby posiadane przez korporacje, mogą one również służyć jako organy doradcze w zakresie technologii i kwestiach ekonomicznych. Z drugiej strony problem z korporacjami wielonarodowymi lub ponadnarodowymi to ich odpowiedzialność prawna i rzetelność, a także przestrzeganie standardów etycznych. Zgodnie z raportem badawczym Greniera (z 2003 r.) około 90\% największych firm międzynarodowych w Europie już kilkanaście lat temu starało się w swoich sprawozdaniach dołączać oświadczenia dotyczące etyki. Niemniej jednak jakość komunikatów jest zróżnicowana i generalnie lepiej oceniane są zagadnienia związane z ochroną środowiska niż praw człowieka. Jednak rosnące oczekiwania społeczne wobec firm ponadnarodowych wynikają z tego, że korporacje coraz częściej kładą nacisk na społeczną odpowiedzialność biznesu i szanują ją, a tym samym uwzględniają odpowiednie narzędzia w strategiach biznesowych, a także w ramach samej misji i wizji firmy.

Think-tanki, a zwłaszcza media i komunikacja masowa są ważnymi podmiotami w kształtowaniu opinii publicznej, wpływając na nią w taki sposób, który jest zgodny z ich potrzebami i interesem, a który postrzegają jako „właściwy”. Biorąc pod uwagę, że korporacje medialne, a także wiele think-tanków należą do konkretnych osób lub instytucji, jest więcej niż oczywiste, że staną one zawsze w obronie interesów ich właścicieli (politycznych albo ekonomicznych). Jeśli są własnością rządów lub podmiotów prywatnych, zawsze będą próbować manipulować opinią publiczną mniej lub bardziej jawnie czy bezceremonialnie. Dopóki jest tylko perswazja, nie czyni ona wiele złego, ale często używa się narzędzi propagandowych $\mathrm{w}$ celu manipulowania społeczeństwem. Z pewnością większy dostęp społeczeństwa do informacji służy również pozytywnym procesom, takim jak zwiększona przejrzystość, a także świadomość procesów politycznych i społeczno-gospodarczych oraz poczucie włączenia społecznego poprzez (czasem jedynie iluzoryczne) uczestnictwo w procesach politycznych.

Bardzo interesującym i w pewnym sensie unikatowym aktorem transnarodowym (także jednym z najstarszych i największych) jest Kościół katolicki. Koncentruje się on na ustanawianiu pewnych przekonań, war- 
tości, norm, tradycji oraz kultury i działa nie tylko poprzez samą instytucję Kościoła, ale także poprzez założenie szeregu innych powiązanych organów, takich jak zakony religijne, wspólnoty kościelne, szkoły katolickie, uniwersytety, media, a nawet partie polityczne w celu dotarcia do jak najszerszych kręgów społecznych. W ten sposób Kościół odnosi się do prawie wszystkich sfer ludzkiego życia, przy czym najwięcej uwagi poświęca prawom człowieka, pokojowi i bezpieczeństwu oraz kwestiom związanym z kulturą. Kościół katolicki jest ciekawym zjawiskiem również dlatego, że próbuje kontrolować wewnętrzne napięcia i zachować równowagę między jednością i różnorodnością (Ryall, 2001).

Partie polityczne jako międzynarodowe podmioty niepaństwowe są zjawiskiem względnie nowym. Partie polityczne to twór XIX wieku, który powstał wraz z pojawieniem się nowoczesnej koncepcji państwa narodowego i idei demokracji przedstawicielskiej. Wyrażały one szczególne preferencje społeczne i przekonania w danym państwie. Początkowo internacjonalizacja partii politycznych polegała na współpracy pomiędzy relatywnie równymi partnerami, a później zaczęła być narzędziem do socjalizacji partii i podporządkowania się najsilniejszym (najbardziej aktywnym i dobrze finansowanym) członkom (Smith, 2001). Integracja europejska wzmogła proces erupcji ponadnarodowych partii politycznych, rzucając tym samym wyzwanie tradycyjnemu podejściu i funkcjom partii politycznych. Ponadpaństwowe partie polityczne funkcjonujące na szczeblu europejskim rozpoczęły swoją działalność w latach 90 . XX wieku, chociaż nieformalne ponadnarodowe ugrupowania polityczne istniały także wcześniej. Najciekawszą kwestią jest to, że odzwierciedlały preferencje polityczne, a nie przynależność państwową. Działalność ponadnarodowych partii politycznych zaciera granice między sprawami rządowymi a pozarządowymi, jak również sprawami krajowymi i międzynarodowymi (Smith, 2001). Pomaga również ustabilizować i krystalizować politykę opartą o partie polityczne, szczególnie w tzw. młodych demokracjach dzięki procesowi socjalizacji i uczenia się (zdobywania doświadczeń).

Warto też wspomnieć o bardzo specyficznym aktorze niepaństwowym, mianowicie o diasporach. Są one bardzo ważnym elementem systemu lobbingu politycznego i potężnym narzędziem wpływu - zarówno na kraj pochodzenia, jak i kraje przyjmujące - w odniesieniu do spraw politycznych, gospodarczych i społecznych, a tym samym pośrednio także do bezpieczeństwa. $Z$ jednej strony mogą próbować walczyć o własne prawa w kraju przyjmującym, a także być pomostem albo kością niezgody pomiędzy państwem goszczącym a krajem macierzystym. Mogą być 
źródłem destabilizacji w kraju przyjmującym i ważnym elementem kampanii wyborczej lub być narzędziem w polityce zagranicznej zarówno dla kraju przyjmującego, jak i macierzystego. Diaspory mogą również wykorzystać swój wpływ, aby osiagnąć własne cele (polityczne, gospodarcze, społeczne), a nawet próbować wpływać na politykę zagraniczną kraju przyjmującego lub macierzystego, a nawet jednego i drugiego. Jak słusznie zauważyła Eva Østergaard-Nielsen (2001, s. 232), ,polityka diaspory [...] często odgrywa kluczową rolę we wspieraniu rodaków z powodów etnicznych, religijnych lub politycznych w wewnętrznych konfliktach w ojczyźnie". Dlatego aktorzy ci, czasami manipulowani latami przez swoje kraje ojczyste, mogą stać się niebezpiecznym narzędziem w rękach niektórych rządów zaangażowanych w konflikty międzypaństwowe. Taka sytuacja dotyczyła mniejszości rosyjskiej w Gruzji oraz na Ukrainie i tego, w jaki sposób się nią posłużono szczególnie w przypadku aneksji Krymu. Diaspory bardzo często zwracają się również do organizacji międzynarodowych i przenoszą interesujące je sprawy na forum międzynarodowe poprzez odniesienie się do kwestii praw człowieka lub problemów związanych z demokracją czy praworządnością. To gwarantuje im posłuch i zainteresowanie społeczności międzynarodowej bez oskarżania o podwójną lojalność (wobec kraju pochodzenia i kraju przyjmującego).

Ostatnim typem aktorów niepaństwowych są grupy zbrojne. Ich pojawienie się jest do pewnego stopnia związane z prywatyzacją siły i działań wojennych. Niepaństwowa grupa zbrojna może być określona jako posiadająca „minimalny stopień spójności jako organizacja prowadząca działania zbrojne przez pewien czas" (Malthanner, 2007, s. 11-12). Istnieją różne typologie niepaństwowych grup zbrojnych, np. podział na: grupy powstańcze, bojówki, gangi miejskie, sieci przestępcze, prywatnych wojowników, siły policyjne i firmy ochroniarskie oraz grupy ponadnarodowe (Krause, 2010). Inną ciekawą kategoryzację proponuja Shultz, Farah i Lochard, dzieląc grupy zbrojne na: powstańców, terrorystów, bojówkarzy i zorganizowane grupy przestępcze (Shultz, 2004). Ten ostatni podział wyraźnie nie obejmuje prywatnych firm ochroniarskich, które powinny zostać uwzględnione, ponieważ stają się one coraz liczniejsze i bardziej powszechne, a zatem odgrywają coraz ważniejszą rolę w kształtowaniu środowiska (nie?)bezpieczeństwa. Można się zgodzić z K. Krause'em i J. Milliken'em (2010, s. 1), którzy twierdza, że „pozapaństwowe grupy zbrojne stanowią bezpośrednie wyzwanie dla westfalskiego projektu budowy suwerennych państw, które posiadaja zarówno prawny Weberiański, jak i praktyczny monopol legalnego uży- 
cia siły na danym terytorium”. Często jest tak, że wzajemne powiązania między państwem i jego instytucjami a niepaństwowymi grupami zbrojnymi są złożone i skomplikowane. Wielu badaczy stosunków międzynarodowych rozumie również związek między niestabilnością, słabością i ubóstwem (niedorozwój) państwa, a pojawieniem się niepaństwowych grup zbrojnych. Wyzwania stawiane przez pozapaństwowe grupy zbrojne są szczególnie destabilizujące w krajach ubogich i słabiej rozwiniętych, gdzie niedostatek idzie $\mathrm{w}$ parze $\mathrm{z}$ niezadowoleniem politycznym i frustracją, praktykami autorytarnymi i różnymi formami wykluczenia (Collier, Elliott i in., 2003). W takich okolicznościach gwałtowne ataki na państwa i reżimy rządzące zarówno wewnątrz kraju, jak i na arenie międzynarodowej są znacznie bardziej powszechne i prawdopodobne. Jednak nie oznacza to, że zjawisko to nie dotyczy politycznie stabilnych i demokratycznych krajów. W pierwszym przypadku grupy zbrojne będą miały charakter partyzancki, bojówkarski czy przestępczości zorganizowanej lub terroryzmu. W drugim, skoncentrują się bardziej na gospodarkach lokalnych, ponadnarodowych sieciach handlowych i przemycie, a także mafiach i prywatnych firmach zajmujących się bezpieczeństwem, jak również międzynarodowych sieciach przestępczych. Prywatne firmy zajmujące się bezpieczeństwem są szczególnie popularne na obszarach miejskich Południa, w krajach, w których policja lub siły bezpieczeństwa są skorumpowane, a ich rzetelność i wiarygodność jest kwestionowana. Jest to najprostszy sposób na to, aby państwo stopniowo traciło swoją siłę i legitymizację korzystania z władzy, przestawało móc zagwarantować ochronę własnego społeczeństwa i realizować podstawowe prerogatywy.

Ostatnią kategorią grup uzbrojonych jest narodowy ruch wyzwolenia, który w rzeczywistości niekoniecznie jest postrzegany jako aktor pozapaństwowy, zwłaszcza przez samych członków takiego ruchu. Mogą one chcieć być postrzegane jako ciała państwotwórcze (z uwagi na ich rzeczywisty status i/lub aspiracje) i mogą być uznane za takie przez niektóre organizacje międzynarodowe (także międzyrządowe). Zgodnie z Protokołem I do Konwencji Genewskich z 1977 r., ruchy wyzwoleńcze mają prawo żądać praw i mogą podlegać międzynarodowym obowiązkom, nawet w przypadku braku posiadania kontroli nad terytorium (Clapham, 2006).

Podsumowując analizę dotyczącą aktorów niepaństwowych, pojawia się pytanie o jednostkę. Czy rola indywidualnego przywództwa jest istotna i czy jest wystarczająco oddzielona od interesów państwowych (jednostka może być postrzegana jako przedstawiciel państwa), by postrzegać ją jako mającą wpływ na rozwój stosunków międzynarodowych i bezpie- 
czeństwa, a także ich instytucjonalizację? Bez wątpienia jednostki mają potencjał i możliwość zwrócenia uwagi publicznej i rządu na konkretne kwestie. Jak twierdzi Breitmeier (2008, s. 48) ,jednostki mogą być politycznymi aktywistami działającymi na płaszczyźnie międzynarodowej i podejmować wysiłki w celu wciagnięcia określonej sprawy do agendy transnarodowej, sformułowania rozwiązań politycznych lub wykorzystania okazji do promowania swoich projektów politycznych w systemach zarządzania globalnego". Jest to prawdopodobnie jedna z najbardziej ekscytujących kwestii, które należy dalej badać w kontekście podmiotów niepaństwowych. Zatem pytanie, czy wkład jednostki do zarządzania globalnego jest wystarczająco istotny, aby traktować ją jako osobny typ aktora niepaństwowego, pozostaje otwarte.

Jak pokazuje powyższa analiza, aktorów niepaństwowych cechuje wysoki stopień heterogeniczności. Ich działalność i zaangażowanie w rozwój stosunków międzynarodowych oraz bezpieczeństwa różni się w zależności od zasięgu, intensywności, obszaru i jakości tychże działań. Nie ulega jednak wątpliwości, że ich rola w kształtowaniu środowiska bezpieczeństwa jest znaczna, a możliwości jeszcze większe. Nawet ONZ założyła, że podmioty niepaństwowe mogą przyczynić się do poprawy legitymizacji zarządzania globalnego (Deklaracja Milenijna Zgromadzenia Ogólnego Organizacji Narodów Zjednoczonych).

Przedstawiona analiza wskazuje na powolne przesuwanie się siły sprawczej z państw do podmiotów niepaństwowych, których rola w międzynarodowej polityce i bezpieczeństwie stale rośnie. Powolna dyfuzja państwa narodowego jest spowodowana przez dwie sprzeczne tendencje: integrację i rozpad. Jak słusznie zauważyli Tofflerowie, „najbardziej dynamiczne sektory nowego ładu gospodarczego nie mają charakteru narodowego, tylko regionalny lub ponadpaństwowy" (Toffler, Toffler, 1994, s. 274). Z drugiej strony, istnieją lokalne siły odśrodkowe, mające na celu tworzenie małych społeczności lokalnych o dużej autonomii. Wynika to głównie z różnic rozwojowych i ekonomiczno-finansowych, które są przedstawiane opinii publicznej jako dążenie do odrębnej tożsamości narodowej, etnicznej lub religijnej. To z kolei determinuje powstanie nowego rodzaju konfliktu i wojny, w którym państwa nie są już głównymi graczami. Dlatego też przyszłymi decydentami nie będą państwa, lecz aktorzy niepaństwowi: międzynarodowe korporacje kierujące się własnym interesem i współpracujące z lokalnymi autonomicznymi władzami. Zatem w sposób znaczący zmienią się zarówno relacje na arenie międzynarodowej, jak i rola poszczególnych graczy w kształtowaniu bezpieczeń- 
stwa globalnego. Podobnie pojęcie wojny będzie musiało zostać poddane ponownej analizie i być może nawet zdefiniowane na nowo.

\section{Bibliografia}

Abrahamsen R., Williams M. C. (2001), Security Beyond the State: Private Security in International Politics, Cambridge University Press, Cambridge.

Alston P. (2005), Non-State Actors and Human Rights, Oxford University Press, Oxford.

Arts B., Noortmann M., Reinalda B. (2001), Non-State Actors in International Relations, Ashgate, Aldershot.

Arts B. (2003), Non-State Actors in Global Governance: Three Faces of Power, Working Paper, Max Planck Project Group on Common Goods, Bonn.

Białoskórski R. (2010), Wyzwania i zagrożenia bezpieczeństwa XXI wieku, Wydawnictwo Wyższej Szkoły Cła i Logistyki, Warszawa.

Breitmeier H. (2008), The Legitimacy of International Regimes, Ashgate, Farnham.

Clapham A. (2006), Human Rights Obligations of Non-State Actors, Oxford University Press, Oxford.

Collier P., Elliott V. L., Hegre H., Hoeffler A., Reynal-Querol M., Sambanis N. (2003), Breaking the Conflict Trap: Civil War and Development Policy, Oxford University Press, Oxford.

Fearon J., Laitin D. (2003), Ethnicity, Insurgency, and Civil War, „American Political Science Review", vol. 97, nr 1.

Hameiri S., Jones L. (2013), The Politics and Governance of Non-Traditional Security, „International Studies Quarterly”, vol. 57, Issue 3, September.

Haufler V. (1997), Dancing with the Devil: International Business and Environmental Regimes, w: Saving the Seas: Values, Scientists, and International Governance, red. L. A. Brooks, S. D. Van Deveer, University of Maryland Sea Great Publications, Maryland.

Josselin D., Wallace W. (2001), Non-state Actors in World Politics, Palgrave Publishers, London.

Jessop B. (2009), Avoiding Traps, Rescaling States, Governing Europe, w: Leviathan Undone? Towards a Political Economy of Scale, red. R. Keil, R. Mahon, UBC Press, Vancouver.

Kamminga M. T. (2005), The Evolving Status of NGOs under International Law: A Threat to the Inter-State System?, w: Non-State Actors and Human Rights, red. P. Alston, Oxford University Press, Oxford.

Krause K. (2010), Armed Groups and Contemporary Conflicts: Challenging the Weberian State, Routledge, London.

Malthanner S. (2007), The 'Armed Groups Database': Aims, Sources, and Methodol$o g y$, ,Working Papers Micropolitics”, nr 2. 
Mann M. (1993), Nation-states in Europe and other continents: diversifying, developing, not dying, „Daedalus”, nr 122(3).

Muchliński P. (2010), Multinational Enterprises as Actors in International Law: Creating 'Soft Law'Obligations and 'Hard Law'Rights, w: Non-State Actor Dynamics in International Law, red. M. Noortmann, C. Ryngaert, Ashgate, Farnham.

Østergaard-Nielsen E. (2001), Diasporas in World Politics, w: Non-state Actors in World Politics, red. D. Josselin, W. Wallace, Palgrave Publishers, London.

Reinalda B. (1997), 'Dea ex Machina'or the Interplay between National and International Policy making? A Critical Analysis of Women in the European Union, w: Sex Equality Policy in Western Europe, red. F. Gardiner, Routledge, London.

Reinish A. (2005), The Changing International Legal Framework for Dealing with Non-State Actors, w: Non-State Actors and Human Rights, red. P. Alston, Oxford University Press.

Rourke J. T. (2008), International Politics on the World Stage, McGraw-Hill, Boston.

Ryall D. (2001), The Catholic Church as a Transnational Actor, w: Non-state Actors in World Politics, red. D. Josselin, W. Wallace, Palgrave Publishers, London.

Sassen S. (2006), Territory, Authority, Rights: From Medieval to Global Assemblages, Princeton University Press, Princeton.

Shultz R., Farah D., Lochard I. V. (2004), Armed Groups: A Tier-One Security Priority, „INSS Occasional Paper”, nr 57, September.

Smith J. (2001), Political Parties in a Global Age, w: Non-state Actors in World Politics, red. D. Josselin, W. Wallace, Palgrave Publishers, London.

Stiles K. W. (2005), Grassroots empowerment: States, non-state actors and global policy formulation, w: Non-State Actors and Authority in the Global System, red. R. A. Higgott, G. R. D. Underhill, A. Bieler, Routledge, London.

Toffler A., Toffler H. (1994), War and Anti-War: Survival at the Dawn of the 21st Century, Warner Books, London.

\section{Role of non-state actors in shaping security}

\section{Summary}

The article presents the analysis of the role of non-state actors in shaping global security. It points out the functions performed by states and the observation that their role is gradually diminishing in favor of non-state actors. The article also presents the classification of these actors (governmental and non-governmental organizations, corporations, militias, think-tanks, diasporas, political parties and the Catholic Church) differentiating their significance for international security.

Key words: states, non-state actors, security, corporations, international organizations 